Australian Journal of Ecology, Vol.23, no.1, 1998, pp.53-67.

http://www.blackwellpublishing.com

(C) 1998 Blackwell Publishing

\title{
Predicting impact of freshwater exotic species on native biodiversity: Challenges in spatial scaling
}

\author{
DAVID M. LODGE ${ }^{1}$, ROY A. STEIN ${ }^{2}$, KENNETH M. BROWN ${ }^{3}$, ALAN P. COVICH ${ }^{4}$, \\ CHRISTER BRONMARK ${ }^{5}$, JAMES E. GARVEY ${ }^{6}$ AND STEVEN P. KLOSIEWSKI ${ }^{7}$ \\ ${ }^{1}$ Department of Biological Sciences, University of Notre Dame, ${ }^{2}$ Aquatic Ecology Laboratory, Department of \\ Zoology, Ohio State University, ${ }^{3}$ Department of Zoology and Physiology, Louisiana State University, ${ }^{4}$ Department \\ of Fisheries and Wildlife, Colorado State University, ${ }^{5}$ Department of Ecology, University of Lund, Sweden, \\ ${ }^{6}$ Aquatic Ecology Laboratory, Department of Zoology, Ohio State University, ${ }^{7}$ U.S. Fish and Wildlife Service, \\ Anchorage, AK.
}

\begin{abstract}
Global homogenization of biota is underway through worldwide introduction and establishment of nonindigenous (exotic) species. Freshwater ecologists should devote more attention to exotic species for two reasons. First, exotics provide an opportunity to test hypotheses about what characteristics of species or habitats are related to successful establishment or invasibility, respectively. Second, predicting which species will cause large ecological change is an important challenge for natural resource managers. Rigorous statistical relationships linking species characteristics to probability of establishment or of causing ecological impacts are needed. In addition, it is important to know how reliable different sorts of experiments are in guiding predictions. We address this issue with different spatial scales of experiments testing the impact of two predators on native snail assemblages in northern Wisconsin USA lakes: an exotic crayfish, the rusty crayfish (Orconectes rusticus); and a native fish predator, the pumpkinseed sunfish (Lepomis gibossus). For the crayfish, laboratory experiments, a field cage experiment, and a snapshot survey of 21 lakes gave consistent results: the crayfish reduced abundance and species richness of native snails. Laboratory and field experiments suggested that pumpkinseed sunfish should have a similar impact, but the lake survey suggested little impact. Unfortunately, no algorithms exist to guide scaling up from small-scale experiments to the whole-lake, long-term management scale. To protect native biodiversity, management of freshwater exotic species should be targeted on lakes or drainages that are both vulnerable to colonization by an exotic, and that harbour endemic species. Management should focus on preventing introduction because eradication after establishment is usually not possible.
\end{abstract}

\section{INTRODUCTION}

Establishment of non-indigenous (or exotic) species has been increasing worldwide since data collection began (US Congress 1993; Ruesink et al. 1995; Vitousek et al. 1996). Many exotics go unnoticed for long periods; most cause no obvious ecological change or economic damage (Williamson \& Fitter 1996). However, a small percentage of exotics cause enormous ecological change, including extinction of native species and changes in community structure and ecosystem function (Nesler \& Bergersen 1991; Pimm 1991; Allan \& Flecker 1993; Lodge 1993a,b; Flecker \& Townsend 1994; Pimm et al. 1995). One of several dramatic examples is the Nile perch (Lates niloticus), which has caused the extinction of many endemic cichlid fishes in Lake Victoria (Cohen 1994; Pitcher \& Hart 1995). Global ecological homogenization, with commensurate loss of species, is the logical endpoint of the anthropogenic spread of exotics (Vitousek et al. 1996).

Compared with terrestrial ecosystems, aquatic ecosystems are particularly vulnerable to exotics for two reasons, both of which result from the strong affinity people have for water for aesthetic reasons, recreation, and transportation. First, relatively intact communities containing $100 \mathrm{~s}-10000 \mathrm{~s}$ of individuals of $10 \mathrm{~s}-1000 \mathrm{~s}$ of pelagic and benthic aquatic species are often trans- 
ported outside the range of many of the constituent species. Vectors include ballast water (Pollard \& Hutchings 1990a,b; Hutchings 1992; Carlton \& Geller 1993), fish bait buckets and live wells of boats (Ludwig \& Leitch 1996), boat trailers and hulls (on which macrophytes and entire epiphytic communities are transported), and shipments of fishes, invertebrates, and macrophytes for aquarium hobbyists, aquaculturists, and water gardens (Arthington 1986; Fletcher 1986; Mitchell 1986; Courtenay \& Stauffer 1990; Schmitz et al. 1991; Carlton 1992). No comparable vectors exist for terrestrial communities, and in the United States, at least, more modest vectors (nursery plants with root balls of soil, agricultural produce, timber) are more tightly controlled and inspected than are aquatic shipments (US Congress 1993).

Second, once introduced into an ecosystem, dispersal may be easier for freshwater than terrestrial species (cf Grosholz 1996 on terrestrial-marine comparisons). This hypothesis has not been rigorously evaluated, but linked systems of lakes and streams, and water movement facilitate dispersal. In addition, fewer dispersal barriers exist in freshwater. One striking example is the rapid establishment of zebra mussel (Dreissena polymorphd) in all the North American Great Lakes and the major river systems of the eastern USA following their accidental establishment via ballast water in Lake St Clair in about 1986 (Johnson \& Carlton 1996). Although the North American Great Lakes ecosystem had already been dramatically transformed by many exotic species beginning in the 19th century (Mills et al. 1993, 1994), the impact of this single exotic finally prompted passage in 1990 of USA federal legislation that began regulation of ballast water discharge in the Great Lakes (Cangelosi 1996). This legislation was a positive step, but policy, research, and management attention should not be fixed on one species. Rather, systematic attention is required on assessments of the dispersal and impact of the full spectrum of actual and potential exotic species.

The study of exotic species is important both for its potentially great contribution to understanding structure of ecological communities, and for natural resource management. In this paper, we argue that existing data sets of introduction of exotic species could be used to test questions central to community ecology, especially with additional monitoring. It would be useful to identify those exotic species most likely to cause ecological change or economic damage in order to efficiently use limited management resources. With a case study of two aquatic predators studied at a range of spatial scales, we assess whether natural resource managers can rely on short-term, small-scale experiments and observations to identify species that may cause ecological disruption. Finally, we conclude with an assessment of the threat of exotic species to global freshwater biodiversity. To focus this paper, we deal primarily with the species richness component of biodiversity. We recognize the importance of other dimensions of biodiversity, e.g. from genetic to landscape diversity (Angermeier \& Karr 1994), and the important links between biodiversity and ecosystem function (Schulze \& Mooney 1993; Jones \& Lawton 1995; Tilman et al. 1996), but focus our attention in this paper at the population and community level.

\section{USE OF EXOTIC INTRODUCTIONS TO TEST CENTRAL QUESTIONS IN COMMUNITY ECOLOGY}

Central questions in community ecology revolve around what characteristics of a community allow it to be susceptible to species additions and, in turn, what characterizes species as good invaders (Pimm 1991). To provide insight into these questions, information is required 
on the number and types of species introduced, their rate of successful establishment, and their impact on the ecosystem. Yet, based on a sampling of the literature, few studies of exotic species incorporate these data (Table 1). As just one example, comparing characteristics of established species with all species introduced (including those that did not survive) would identify species features that permit invasion success. Many characteristics have been championed in the extensive literature on invasions, e.g. body size, diet breadth, $r$, size of native range (reviewed in Lodge 1993a,b; Moyle \& Light 1996), but few have been rigorously tested. Such analyses have been productive for marine palaeoecological communities (Vermeij 1991), for birds introduced to New Zealand (Veltman et al. 1996), and for pines introduced worldwide (Rejmanek \& Richardson 1996).

Most published documentations of introduced aquatic species pools derive from marine and estuarine sampling of ballast waters (e.g. Carlton \& Geller 1993). Ironically, in many of those cases, which of the introduced species became established has not been documented (Table 1). The converse applies for most freshwater situations: ample documentation exists on established exotic species, but the original pool of introduced species has rarely been identified (Table 1). Thus, the statistical comparisons that could address central questions in community ecology are impossible to conduct because the appropriate data are either not being collected or (in the case of government inspection and regulatory agency records) are not readily available.

Likewise, a comparison of the characteristics of the subset of established species that have a major ecological impact with the pool of all established exotics (including those with imperceptible ecological impact) could identify features associated with major ecological or economic impact. If strong statistical associations exist for these and similar comparisons, they would constitute a major advance in research on community assembly and a giant step forward over the conceptual and verbal models of species establishment and impact now promulgated (Vitousek 1990; Lodge 1993a,b; Ruesink et al. 1995).

\section{MULTI-SCALE TESTS OF THE IMPACT OF TWO AQUATIC PREDATORS ON PREY COMMUNITIES}

Identification of potentially high-impact exotic species should be explored first by conceptual models (Lodge 1993a,b; Ruesink et al. 1995) and statistical analyses as described in the previous section, and second by experimental evaluation of species that initial screening suggests may cause ecological change. Finally, species so identified should become the target of measures to prevent introduction, eradication efforts if they are only locally established, or steps to limit spread and impact if they are already widely established.

Most often, species are already established, at least locally, before they are even recognized. Thus, eradication is often not feasible. Thus, die challenge is to establish management priorities based on die best scientific assessment of current impact and prediction of future impact. The crucial question for ecologists is how to conduct an experimental assessment of the potential impact of successful invaders.

Two very difficult components of this challenge exist. First, the spatial and temporal scales of management concern are large and long; frequently they encompass whole lakes and landscapes over time periods of years to decades (Carpenter et al. 1995; Lodge et al. 1997). Experimental work at this scale is difficult and often prohibitively expensive. Even where such research is possible, answers come too slowly to shape management decisions early in an ongoing invasion. Second, it is untenable (and often illegal) to introduce an exotic species for research purposes. Effective conversion of small-scale, short-term results up to large-area, long- 
term patterns (Frost et al. 1988; Karieva \& Andersen 1988; Tilman 1989; Cullen 1990; Giller et al. 1994; Lodge et al. 1997) has immense practical significance, but is not readily and reliably achieved.

We present experimental work on the impact of two predators, one exotic (the rusty crayfish Orconectes rusticus) and one native (the pumpkinseed sunfish Lepomis gibossus), at scales from short-term, small-scale laboratory experiments to a natural snapshot experiment (sensu Diamond 1986). At the whole-lake scale, observed patterns presumably developed over years to decades. Our case study is unusual in that it allows a multi-scale comparison between two species. Because these different scales were pursued in parallel ways by the same group of researchers, we have a rigorous comparison across scales.

For the purpose of exploring how experimental scale affects conclusions about the outcome of biotic interactions, we suggest that it is largely irrelevant that one of our experimental species is a native and the other exotic. To the extent that coevolution or at least long-term coexistence has occurred, a native predator might reasonably be expected to have less of an impact on a prey community than an exotic one (Thorp 1986). Even so, we have no expectation that the results of caging experiments and whole-lake scale experiments

Table 1. Ten data sets on aquatic exotic species, emphasizing the paucity of information on the pool of introduced species

\begin{tabular}{llcccl} 
& & \multicolumn{3}{c}{ Number of exotic species } & \\
Region & Taxa & Introduced & Established & With impact & Source \\
Coos Bay (OR, USA) & Plankton & 5367 & $?$ & $?$ & Carlton and Geller 1993 \\
North Am. Great Lakes & Macrobiota & $?$ & 139 & 13 & Mills ot al. 1993 \\
Hudson River, USA & Macrobiota & $?$ & 113 & 15 & Mills et al. 1996 \\
50 states, USA & Fishes & $?$ & $7-107$ & some & US Congress 1993 \\
North America & Bivalves & $?$ & 6 & $1-2$ ? & McMahon 1991, Neves 1993 \\
Hawaii & Amphibians & $?$ & 4 & $?$ & US Congress 1993 \\
Hawaii & Fishes & $?$ & 29 & Many? & US Congress 1993 \\
Australia & Macrophytes & $?$ & $24-46$ & 11 & Arthington and Mitchell 1986 \\
Australia & Fishes & 24 & 19 & $7 ?$ & Arthington and Bluhdorn 1995 \\
Earth's ancient lakes & Variety & $?$ & $2-210$ & many & Cohen 1994 \\
\hline
\end{tabular}

Lists include species that were transplanted but did not become established. With the exception of Coos Bay, all data sets derive from freshwater ecosystems.

$?=$ not known. Ranges in the Established column refer to different states (USA and Australia) or different lakes (Earth's ancient lakes).

would be more consistent for a native predator than for an exotic or vice-versa.

Reasons for studying snails, crayfish, and pumpkin-seed sunfish were as follows. Snails often dominate aquatic invertebrate assemblages by numbers and bio-mass, and they often have large direct and indirect effects as herbivores on periphyton (Weber \& Lodge 1990; Brönmark et al.. 1992; Lodge et al. 1994; Vermaat 1994; Feminella \& Hawkins 1995).

Like snails, crayfish are often abundant and have high standing biomass; they also are one of the largest freshwater invertebrates (Lodge \& Hill 1994). Abundant evidence has accumulated in recent years that crayfish are quite omnivorous and play an important role in lake and stream food webs (Lodge \& Lorman 1987; Feminella \& Resh 1989; Chambers et al. 1990; Crowl \& Schnell 1990; Hanson et al. 1990; Matthews \& Reynolds 1992; Lodge et al. 1994). In addition, crayfish seem to be one of the few predators that can consume large snails, and behavioural responses of snails suggests that their evolution has been partly shaped by crayfish 
predation (Crowl \& Covich 1990; Alexander \& Covich 1991; Covich et al. 1994).

Among crayfishes, the rusty crayfish has been well studied because of its establishment in many North American locations outside its native range in Indiana, Kentucky, and Ohio (USA) (Hobbs et al. 1989). Newspaper reports of subsequent declines in submersed macrophytes (and fishes, although this has not been well documented) are common in Michigan, Ohio, and Wisconsin (USA) and southern Ontario (Canada). Early in the invasion of Wisconsin lakes (1970s), state regulatory agencies banned the use of live crayfish as fish bait, because fishermen appear to be a major vector of introduction (Ludwig \& Leitch 1996). The environmental constraints on rusty crayfish and congeners (Capelli \& Magnuson 1983; Kershner\& Lodge 1995), the spread of rusty crayfish and its displacement of congeneric crayfishes (Lodge et al. 1986; Olsen et al. 1991; Hill et al. 1993; Hill \& Lodge 1994), and its impact on lake food webs (see citations in sections below) have all been well documented (Lodge \& Hill 1994).

We focused on pumpkinseed sunfish because of their specialized molluscivory (Mittelbach 1984; Osenberg \& Mittelbach 1989; Klosiewski 1991). Earlier work on the strong diet selection by pumpkinseeds among snails (Osenberg \& Mittelbach 1989) supported the expectation that they affect snail species composition in predictable ways. Generalist predators should depress prey populations more than specialists (Murdoch \& Bence 1987). Specialization of the pumpkinseed sunfish diet, then, suggests that pumpkinseed sunfish might depress snails less than the generalist crayfish (Murdoch \& Bence 1987).

Expectations for this case study might then include the following. As both a native species and a specialized predator, pumpkinseed sunfish would be expected

to depress snail populations less than crayfish. However, no clear predictions are possible regarding how results might differ between the two predators in small-scale vs large-scale experiments.

\section{Laboratory aquaria}

Methods: crayfish and pumpkinseed sunfish

Laboratory experiments were conducted primarily to assess how the two predators might affect snail species and size composition, but they also measured feeding rates. Crayfish experiments, in particular, were designed to provide a simple basis for predicting impact in natural lakes; they provided average-sized adult crayfish a choice among the natural summertime assemblage of snail species (at natural size range). In June-July 1990, individual male rusty crayfish (28-30 mm carapace length) were offered four snail species in sizes and relative abundances that were representative of Carrol Lake, WI, as determined by field sampling. In 40 $\mathrm{L}$ aquaria with $3 \mathrm{~cm}$ of sand on the bottom, these snail species and sizes were offered during $20 \mathrm{~h}$ overnight trials $(n=3)$ : Amnicola sp. (3.0-1.5 mm shell length); Gyraulus parvus (1.5-5.0 mm); Physella gyrina (4-7 mm); and Campeloma decisa (7 mm).

For pumpkinseed sunfish of two sizes (120 $\mathrm{mm}$ and $150 \mathrm{~mm}$ total length), we tested preference in 120L laboratory aquaria among three species of snails (Lymnaea ewarginata, Helisotua anceps, and Campeloma decisum), with all snails of $6 \mathrm{~mm}$ shell length. Detailed methods are available in Klosiewski (1991). For both crayfish and pumpkinseed, our methods and data satisfied the assumptions of Manly's alpha preference index for non-replacement of prey (Krebs 1989).

Results and Discussion: crayfish 
Crayfish had high feeding rates on snails (Fig. 1), suggesting their potential to reduce snail abundance in natural lakes, depending of course on abundance of the predators in lakes. Of more relevance to field predictions, crayfish were also selective among these species (which also differed in size). Figure 1 is illustrative of the selectivity exhibited by crayfish in a series of such laboratory experiments (K. M. Brown unpubl. data). By chipping away at crushable shells, crayfish can consume even very large-shelled molluscs (Perry et al. in press); they are not gapelimited on these shells. For thick-shelled mollusca such as Corbicula, crayfish can penetrate and enlarge weak sections of shells, but for strong, intact shells, they are limited to consuming shells smaller than $4 \mathrm{~mm}$ in shell length (Covich et al. 1981).

The conclusion from these experiments was that crayfish selected strongly against Campeloma (Fig. 1) and Helisoma (K. M. Brown unpubl. data), probably because the shells of these species are extremely strong (see Fig. 1 in Klosiewski 1991). Whereas selection among other species may have existed in this experiment (Fig. 1), crayfish ate most species at high rates.

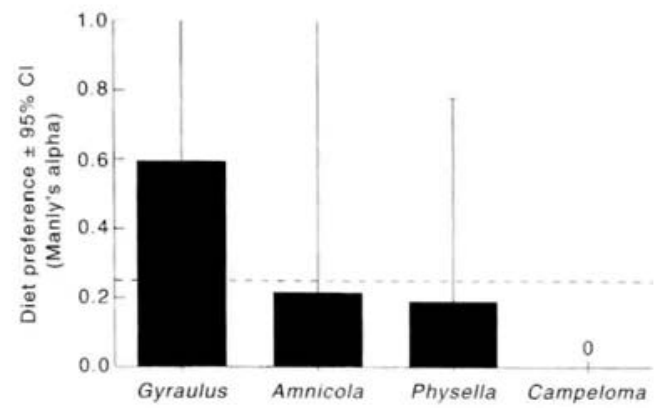

Fig. 1. Prey preference by crayfish among four snail species (which differed in size), relative to the null model of no preference (------). Mean number of snails (69) consumed per crayfish per night provided an index of potential predation rate. 


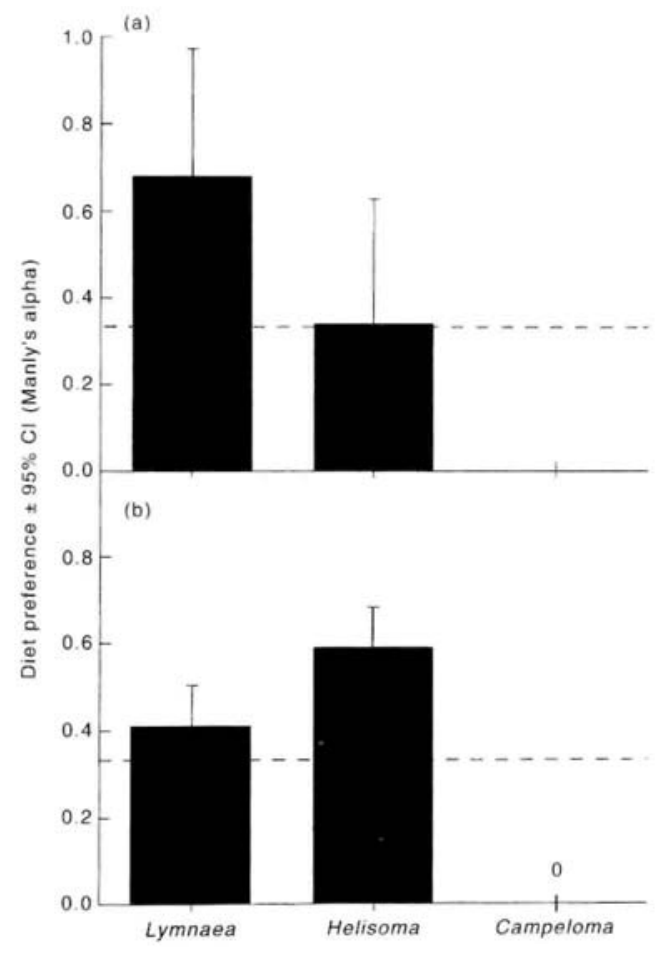

Fig. 2. Species preference by two sizes (total length) of pumpkinseed sunfish (Lepomis) among three species of snails, with all snails of $6 \mathrm{~mm}$ shell length, (a) $120 \mathrm{~mm}$ Lepomis consumed $>68$ snails per fish per hour, (b) 150 Lepomis consumed $>114$ snails per fish per hour. (---) the null model of no preference.

Other laboratory experiments testing size and species selection separately consistently indicated weak size and species selection except for large, thick-shelled species that the crayfish could not chip (A. P. Covich unpubl. data).

On the basis of laboratory results and the observation that crayfish are often abundant in lakes (Hill \& Lodge 1994), we predicted that crayfish should reduce overall snail abundance in more natural settings, thus increasing the proportional representation of Campeloma and Helisoma in natural snail assemblages.

\section{Results and Discussion: pumpkinseed sunfish}

Individual pumpkinseed sunfish had very high feeding rates, perhaps an order of magnitude higher than crayfish on a daily individual basis (compare units on Figs 1,2). The nature of selective predation by pumpkinseeds has been explored in detail by Klosiewski (1991), and results presented here are only one example from an extensive series of laboratory experiments in which size and species selection of different-sized pumpkinseed were tested independently. In contrast to crayfish which are largely tactile feeders, pumpkinseed feed visually and have precise powers of discrimination. Both species selection (Fig. 2) and size selection (Klosiewski 1991) were stronger than for crayfish, and differed among sizes of pumpkinseed (Fig. 2) on the basis of shell crushability and gape-limitation (Klosiewski 1991).

Based on these results, Klosiewski (1991) concluded that lakes with high abundance of pumpkinseeds should have snail assemblages dominated by small and/or thick-shelled species. In particular, small thick-shelled species like Amnicola should be least vulnerable regardless of 
pumpkinseed size: small fish select against strong-shelled snails and large fish select for large snails. In the absence of pumpkinseeds, large, weak-shelled snail species should be more abundant (Klosiewski 1991).

\section{Field cages}

Methods: crayfish and pumpkinseed sunfish

We tested the laboratory-generated predictions of the impacts of crayfish and pumpkinseeds in the more realistic setting of $9 \mathrm{~m}^{2}$ cages within natural Wisconsin lakes. Lakes were chosen that contained only a low abundance of the test predator, to minimize past impact of the predator on prey. For crayfish, we installed enclosures and exclosures in Plum Lake, Wisconsin $(n=4)$; for pumpkinseed, we installed enclosures and exclosures in Round Lake, Wisconsin $(n=5)$. In their respective experiments, the density of the predator in enclosures $(8$ crayfish per $\mathrm{m}^{2}$; 0.33 pumpkinseed sunfish per $\mathrm{m}^{2}$ ) was within the range of natural densities in northern Wisconsin lakes. The duration of experiments was 11 weeks for crayfish and 15 months for pumpkinseed sunfish. Details of methods are provided in Lodge et al. (1994) for crayfish, and in Klosiewski (1991) and Brönmark et al. (1992) for pumpkinseed sunfish.

\section{Results and Discussion: crayfish and pumpkinseed sunfish}

Both crayfish (Lodge et al. 1994) and pumpkinseed sunfish (Brönmark et al. 1992) reduced overall snail abundance by $99 \%$ and $82 \%$, respectively. Also, as expected, both predators reduced species number: crayfish by $50 \%$ and pumpkinseed by $33 \%$ (Fig. 3). Campeloma, as predicted, was one of only three species remaining in the presence of crayfish at the conclusion of the experiment, but much of the reduction of species number by crayfish is attributable to rarefaction (Lodge et al. 1994). Although the total reduction of species number by pumpkinseed sunfish was more modest than that of crayfish, their impact on the relative abundance of species was greater than that of crayfish, consistent with the results of laboratory experiments. Large, weak-shelled species, e.g. Physella, increased greatly in the absence of pumpkinseed sunfish (Klosiewski 1991).

Overall, then, results of field caging experiments were consistent with expectations. Pumpkinseed sunfish, the specialized native predator, reduced snail abundance less than crayfish, the generalized exotic predator. Laboratory results on prey selection accurately predicted the impact of both predators on snail species composition in small enclosures. The general patterns observed in field cages, lower snail abundance and shifted species composition in the presence of crayfish or pumpkinseed sunfish, were then predicted to occur in whole lakes on an even more realistic spatial scale.

\section{Natural lakes}

Given the results of laboratory and field cage experiments reviewed above, in which 


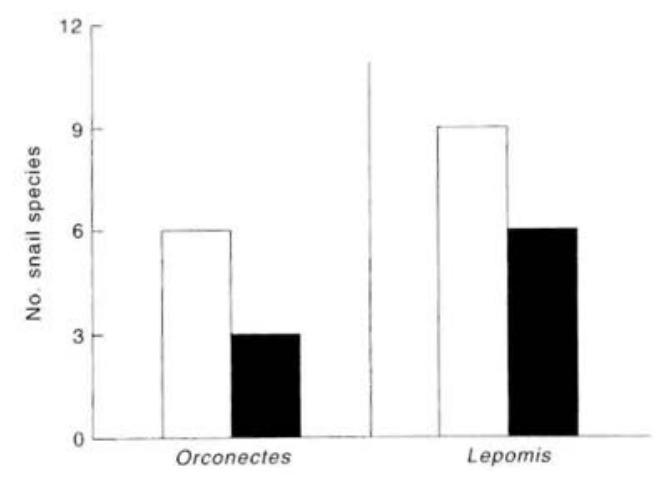

Fig. 3. Impact of rusty crayfish (Orconectes; from Lodge et al. 1994) and pumpkinseed sunfish (Lepomis; from Klosiewski 1991) on mean snail species number in independent field cage experiments. ( $\square$ ) exclosure; (๘) enclosure.

both crayfish and pumpkinseed predators had strong negative effects on snail abundance and species number, we predicted that both snail abundance and species number would be negatively related to predator abundance in natural lakes. To test this prediction, we conducted a snapshot natural experiment (sensu Diamond 1986). Whereas natural experiments have obvious weaknesses relative to smaller scale and more tightly controlled experiments (little regulation of independent variables, difficult site matching, assumption of at least quasi-equilibrium, etc.), their strengths, especially with respect to management concerns cannot be matched by smaller experiments (Lodge et al. 1997). These include greater spatial scale, greater temporal scale (under the assumption that the observed pattern is an equilibrium resulting from long-term processes), greater realism, and greater generality (Diamond 1986). In addition, natural experiments are usually the only ethically acceptable method to assess the impact of exotics at a large scale. Given the weaknesses of natural experiments, however, confidence in their interpretation is enhanced by results of more mechanistic laboratory and field experiments similar to those reviewed above (Diamond 1986).

\section{Methods}

In summer 1987, after preliminary sampling of crayfish and pumpkinseed sunfish (but not snails), 21 northern Wisconsin lakes $\left(45^{\circ}-46^{\circ} \mathrm{N}, 89^{\circ}-90^{\circ} \mathrm{W}\right)$ were selected for more intensive sampling of crayfish, pumpkinseed sunfish, and snails. The final choice included 5 lakes with high abundance of crayfish, 5 lakes with high abundance of pumpkinseed sunfish, and 11 lakes with low abundance of both. No lake had both abundant pumpkinseed sunfish and abundant crayfish, because lakes with abundant pumpkinseed sunfish tended to be dominated by soft organic sediments (and therefore had abundant macrophytes), conditions unfavourable for crayfish (Lodge \& Hill 1994). The abundance of Orconectes is positively related to substrate firmness (Hill \& Lodge 1994; Lodge \& Hill 1994; Kershner \& Lodge 1995).

The lakes ranged in area from 21 to 518 ha and had maximum depths of 2-27 m. All were circumneutral lakes with adequate calcium for snails (Lodge et al. 1987) and crayfish (Lodge \& Hill 1994). Before intensive sampling, maps of habitat type in the littoral zone were prepared, with habitat categorized as either unvegetated sediments, vegetated, or rocky. For every habitat type present, we divided the entire lake littoral zone into 12 equal-shoreline length sectors. Thus, in lakes with three habitats, we divided the lake perimeter into 36 sectors; with two habitats, 24 sectors; and with one habitat, we sampled 12 sectors. Thus, sector number (and consequently 
sampling effort) increased as habitat heterogeneity increased. Because lakes were different sizes, sector size differed among lakes. This sampling strategy did not result in biased estimation of snail species number; no relationship existed between snail species number per lake and the number of sectors sampled per lake $\left(r^{2}=0.02, P=0.52\right)$. In each lake, sample position was randomized within the first sector; this relative position was then sampled within every sector of that lake.

Snails were collected during June. SCUBA divers collected one circular core $\left(0.018 \mathrm{~m}^{2}\right.$, $\geq 5 \mathrm{~cm}$ depth in sediments) within each sector of each lake to determine snail abundance. In rocky habitats, where cores were unusable, different-sized rings were used (depending on snail abundance) to delineate one area per sector $\left(0.1-0.5 \mathrm{~m}^{2}\right)$, from which all surficial rocks were collected by a diver and transferred to a boat for removal of all snails. In the laboratory, snails were separated from sediments and other debris by sieving $(1 \mathrm{~mm})$. Crayfish were sampled during 22 July to 26 August 1987, by setting one trap in each sector using standard trap opening size and bait, as described by Lodge et al. (1986). Only male catches are analysed because they provide the best index of crayfish abundance (Lodge et al. 1986). The abundances of pumpkinseed sunfish were estimated along $50 \mathrm{~m}$ transects, using an electrofishing boat at night (1 June to 31 August) in 5-11 sectors per lake. Sampling effort was disproportionately concentrated in macrophyte habitats because this is where pumpkinseed sunfish were most abundant. In addition, at least one sector of each habitat type present was sampled. Time precluded electrofishing every sector.

We conducted a two-dimensional Kolmogorov-Smirnov test to compare the joint distribution of predator and prey to the distribution expected if predator and prey abundances were independent (Fasano \& Franceschini 1987; Press et al. 1992; Garvey et al. in press). Each test generated a test statistic, $D$, representing the maximum point of departure between the observed and expected distributions. To determine the significance for each test, we randomized the observed X,Y pairs 5000 times (Manly 1991), determining the proportion of randomly generated $D$ 's exceeding the actual test statistic. If this proportion exceeded 0.05 , we concluded that the observed pattern may have been generated by chance.

We analysed the lake survey data at two spatial scales. At the smallest spatial scale, we plotted the predator and prey abundance from each sector of each lake. Because pumpkinseed sunfish were sampled in fewer sectors than crayfish, this sector-scale analysis for pumpkinseed sunfish was based on fewer data than for crayfish. Our sector-scale analyses essentially address the within-lake pattern of co-occurrence of predator and prey; however, we could not effectively conduct this test for each lake independently because many lakes lacked a broad range of predator densities across sectors. Therefore, we pooled the data across all lakes to test the sectorscale pattern. Because data from multiple sectors within one lake may not be independent, our sector-scale analyses must be interpreted with caution.

To be conservative in our sector-scale analyses, we eliminated 0,0 coordinates from the data sets because the mutual absence of predator and prey may indicate a habitat that is simply unsuitable for both and therefore not a habitat appropriate to test the impact of predator on prey. In addition, large numbers of 0,0 data points biased the Kolmogorov-Smimov test toward significance.

At the largest spatial scale, we plotted the mean lake-wide abundance of predator against the mean lake-wide abundance of prey. Thus, each datum on these plots represents a lake. Lakewide number of snail species was the total number of snail species sampled in each lake (regardless of abundance). For snail abundance and crayfish abundance, the lake-wide means for 
each of the 21 lakes was based on 12-36 sectors, depending on how many of the three habitat categories (unvegetated sediments, vegetated, or rocky) were present in each lake. Visual inspection of scatterplots done separately for each of the three habitat types showed that snail abundance was highest in macrophytes and lowest in rocky habitats, but the crayfish-snail pattern was similar to that based on lake-wide means; for simplicity, we present only the lakewide analyses here.

Lake-wide abundance of pumpkinseed sunfish was the habitat-weighted mean of electroshocking transect catches for each lake. Unlike for snails and crayfish, weighting means by habitat type was necessary because habitats were not sampled in proportion to their abundance in lakes. Thus, for a given lake, we calculated mean abundance of pumpkinseed sunfish across transects by weighting each transect-specific abundance estimate (number of pumpkinseed sunfish/transect) by the proportion for that lake of shoreline sectors in that habitat category.

\section{Results and Discussion}

Analysis by lake sector

At the sector scale, the smallest spatial scale at which the lake sampling can be analysed, the predicted negative relationships existed between crayfish abundance and snail abundance (Fig. 4a) and snail species number (Fig. 4b). The impact was so strong that a critical threshold was detected, such that both snail abundance and species number declined to very low levels when crayfish abundance was $\geq 5$ per trap. Where crayfish abundance was $<5$ per trap, snail abundance had very high variance. High variance in prey numbers at low predator abundance could easily have resulted from several factors other than crayfish that also affect snail abundance and species composition (Lodge et al. 1987). Similar, strong threshold patterns have been noted between urchins and kelp (see fig. 7 in Estes \& Duggins 1995), and are interpreted as evidence for strong interaction between predator and prey. Thus, at the scale of variation within lakes, patterns are consistent with our laboratory and field cage results: the exotic crayfish dramatically depresses both snail abundance and snail species number.

For pumpkinseed sunfish, patterns at the sector-scale were not as predicted. Rather, patterns for both snail abundance and species number did not differ from random (Fig. 5).

Analysis by whole lake For crayfish at the whole-lake scale, both snail abundance (Fig. 6a) and snail species number (Fig. 6b) seemed to be negatively related to crayfish abundance. With only 21 lakes, our ability to detect non-random patterns was low, and only the pattern for snail abundance departs from random according to the 2-dimensional Kolmogorov-Smirnov test (Fig. 6a). However, because these data were almost categorical with respect to crayfish abundance (low vs high crayfish), $t$-tests were used to compare the snail responses between lakes with low crayfish abundance $(n=16)$ and high crayfish abundance $(n=5)$, revealing that both snail abundance $(P=0.004$, Fig. 6a) and snail species number $(P=0.001$, Fig. $6 \mathrm{~b})$ were lower in high crayfish relative to low crayfish lakes.

Patterns were not as clear at the whole-lake scale (Fig. 6) as at the sector-scale (Fig. 4). This may result in part from the fact that habitat patches with very low crayfish abundance within a lake with high mean crayfish abundance skewed the snail response (especially species number) to a high mean. Thus, the whole-lake scale, because it integrates heterogenous habitats including those not favoured by crayfish, was a scale larger than the one at which this predatorprey relationship operates. This is further complicated by the fact that fish predators of crayfish (which do not include pumpkinseed sunfish) reduce crayfish abundance (DiDonato \& Lodge 
1993; Garvey et al. 1994), feeding rates (Hill \& Lodge 1995) and use of non-rocky habitats (Kershner \& Lodge 1995), and may therefore contribute to the weaker signal of the crayfishsnail interaction at the whole-lake scale. Nevertheless, the negative impact that crayfish have on snail abundance was manifest strongly across all scales, from $40 \mathrm{~L}$ aquaria to whole lakes.

In contrast, the signal of the predatory impact of pumpkinseed sunfish on snails disappeared at the sector (Fig. 5) and whole-lake (Fig. 7) scales. For both snail abundance

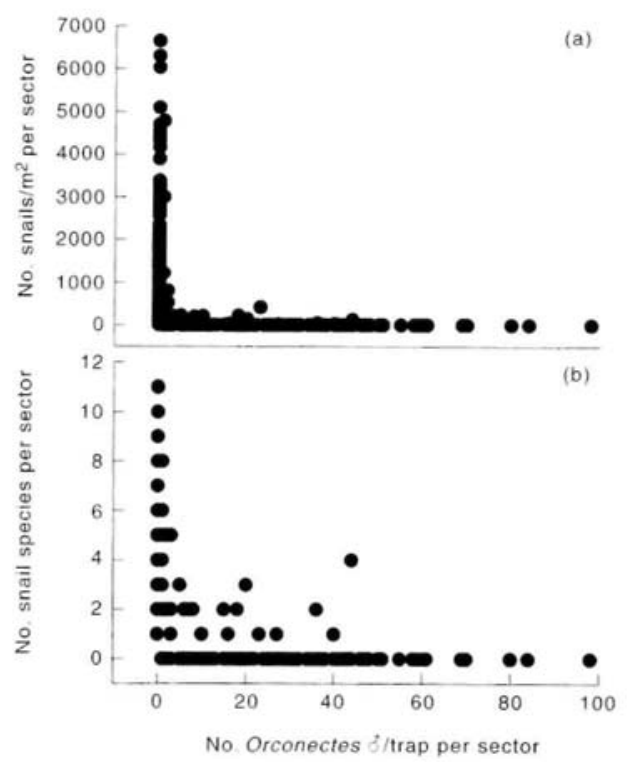

Fig. 4. Relationship of sector-specific snail abundance (a) and sector-specific number of snail species (b) to an index of crayfish (Orcoiiecres) abundance in shoreline sectors of 21 lakes. Zero-zero coordinates were eliminated (although because of some data points with very low values, the plot appears to include zero-zero data). Statistical results test departure of the observed pattern from a random pattern (2-dimensional Kolmogorov-Smirnov test). (a) $D=0.179, P=0.0002, n=375$ sectors, (b) $D=0.178, P=0.0002, n=375$ sectors. 


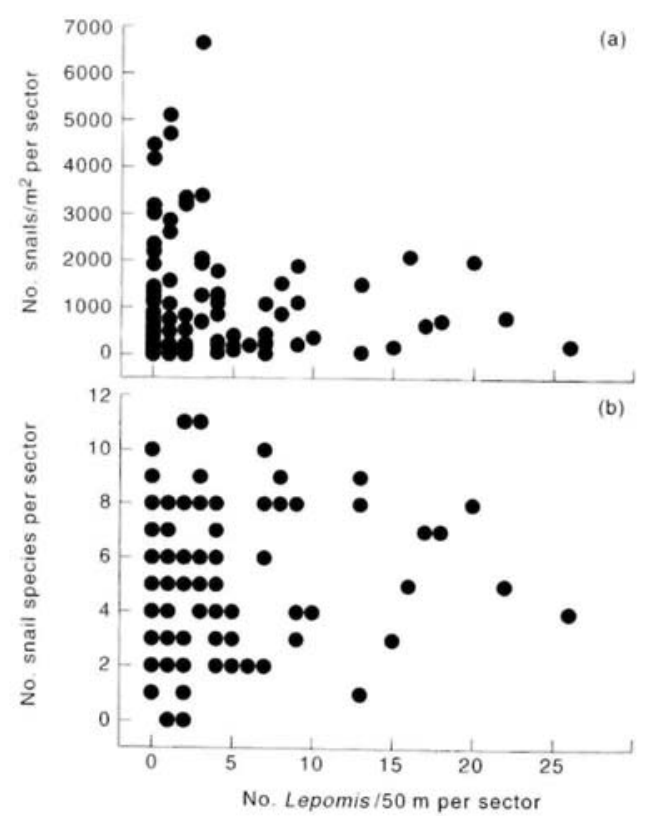

Fig. 5. Relationship of sector-specific snail abundance (a) and the sector-specific number of snail species (b) to an index of pumpkinseed sunfish (Lepomis) abundance in shoreline sectors of 21 lakes. Zero-zero coordinates were eliminated (although because of some data points with very low values, the plot appears to include zero-zero data). Statistical results test departure of the observed pattern from a random pattern (2-dimensional Kolmogorov-Smirnov test), (a) $D=0.039, P=0.53, N=128$ sectors, (b) $D=0.049, P=0.18, n=128$ sectors.

(Figs 5a, 7a) and snail species number (Figs 5b, 7b), the predicted patterns of lower mean abundance of snails and lower snail species number at higher pumpkinseed sunfish abundance clearly did not exist.

Thus, at the larger scales, other factors overshadow the negative impacts of pumpkinseed sunfish on snails that would be predicted by laboratory and field experiments. These factors probably include the positive association that both snails (Brönmark 1985; Lodge el al. 1987; Brown \& Lodge 1993) and pumpkinseeds (R. A. Stein \& S. P. Klosiewski unpubl. data) have with submersed vegetation. Most lakes with high pumpkin-seed sunfish abundance also have extensively vegetated littoral zones. Thus, patches of macrophytes sufficiently dense to provide a predation refuge for snails probably exist in most high pumpkinseed sunfish lakes. With pumpkinseed sunfish, an interaction modification may be at work mat contrasts sharply with the negative impact that crayfish have on both the snails and their macrophyte habitat (see below). Such an interaction modification would be manifest more strongly at the whole-lake scale than at the sector scale, i.e. the sector-scale should exhibit more of the predicted negative association of predator and prey than the whole lake scale. However, our results do not support that prediction. Piscivorous fishes also may dampen the impact of pumpkinseed sunfish on prey, but preliminary analysis of data on all fishes in the 21 lake survey do not support this hypothesis (R. A. Stein \& J. E. Garvey unpubl. data).

There is evidence that the assumption of equilibrium was probably violated with pumpkinseed sunfish. In one of two lakes with more than one year of data, pumpkinseed sunfish abundance declined dramatically as a result of winterkill (Klosiewski 1991). Because lakes with high pumpkinseed sunfish abundance tend to have thick, organic-rich sediments and abundant 
macrophytes, a link between winterkill and pumpkinseed sunfish may often lead to disequilibrium between predator and prey that could only be detected with a natural trajectory experiment (sensu Diamond 1986). In contrast, crayfish abundance is relatively constant in longterm data sets from several Wisconsin lakes (Olsen et al. 1991).

The difference between population dynamics of the two predators, driven perhaps by winterkill on pumpkinseed sunfish, may contribute to the contrasting predatory signals at the whole-lake scale. In addition, the generalist diet of crayfish probably contributes to its stronger

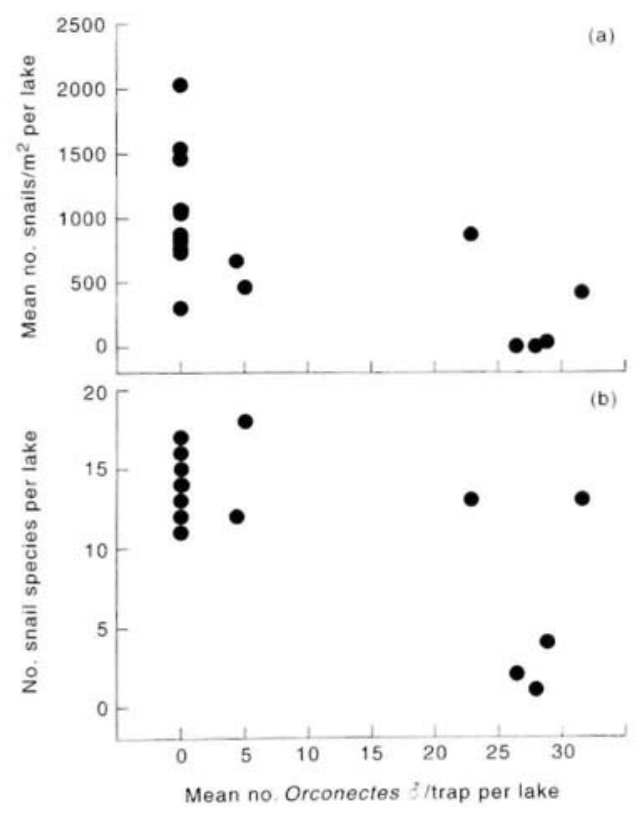

Fig. 6. Relationship of lake-wide snail abundance (a) and the lake-wide number of snail species (b) to an index of crayfish (Orcomctes) abundance in 21 lakes. Statistical results test departure of the observed pattern from a random pattern (2-dimensional Kolmogorov-Smirnov test). (a) $\mathrm{D}=0.16, P=0.012, n=21$ lakes, (b) $D=0.09, P=0.26, n=$ 21 lakes. 


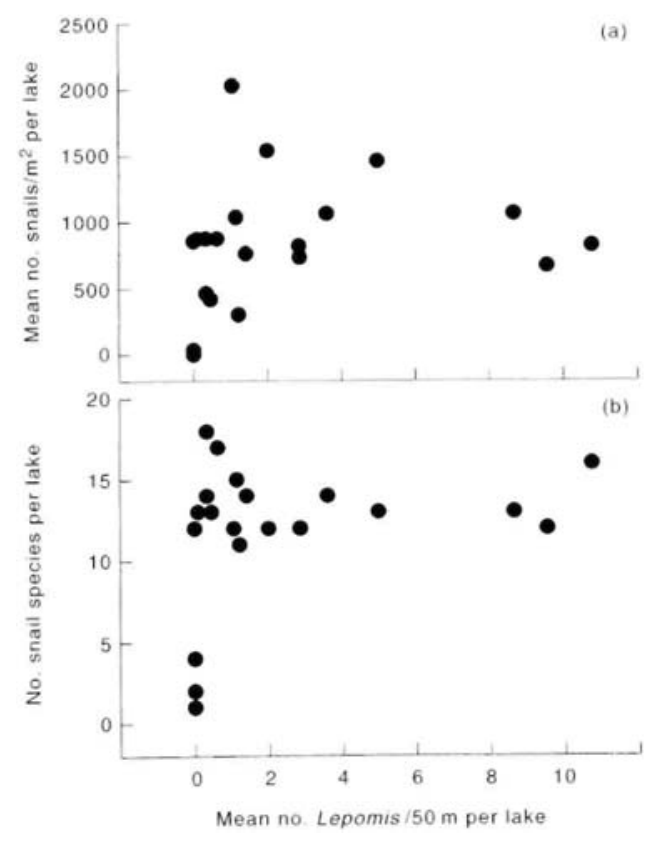

Fig. 7. Relationship of lake-wide snail abundance (a) and the lake-wide number of snail species (b) to an index of pumpkinseed sunfish (Lepomis) abundance across 21 lakes. Statistical results test departure of the observed pattern from a random pattern (2-dimensional Kolmogorov-Smirnov test), (a) $D=0.12, P=0.091, n=21$ lakes, (b) $D=$ $0.12, P=0.095, n=21$ lakes.

negative impact on snails. Crayfish not only eat the snails, but also consume and destroy the macrophyte habitats that typically harbour the highest densities of snails (Lodge et al. 1994). These hypotheses need further testing.

\section{Conclusions of multi-scale tests}

For the crayfish, results were consistent across the whole scale of experiments (Table 2), and hence laboratory experiments would have provided a reliable guide for management decisions. Clearly, the larger-scale and longer-term field experiments and lake surveys provide more insight, accuracy, and precision in predicting impact of the exotic species on native snail assemblages, but their cost and duration make them much less practical and useful for quick action in the face of an advancing exotic species.

For pumpkinseed sunfish, laboratory experiments and field caging experiments provided a misleading picture of the impact of pumpkinseeds on snail assemblages at the sector and whole-lake scale (Table 2). Long-term population fluctuations that likely cause this discrepancy would have been difficult to predict, given the previous lack of study of this non-game fish species. Only long-term data on pumpkinseed sunfish populations would have led to the intuition mat population fluctuations would dampen pumpkinseed sunfish impact on prey. Thus, no substitute existed for large-scale, long-term studies to predict accurately the impact of pumpkinseed sunfish on snails in nature.

Given these contrasting outcomes for crayfish and pumpkinseed sunfish, a further challenge for aquatic ecologists is to discover whether biological interactions involving certain classes of species or habitats are likely to require longer-term studies whereas interactions involving other classes of species or habitats are adequately understood and scaled-up from 
small-scale, short-term experiments. Making this distinction is an extremely vexing challenge for which we have no answer other than the informed biological intuition that we are now forced to rely on. This intuition often fails (as illustrated by the pumpkinseed sunfish example above).

\section{ENDEMISM AND THE IMPACT OF EXOTICS ON NATIVE BIODIVERSITY}

Since its anthropogenic dispersal from Indiana and Kentucky to northern Wisconsin, the rusty crayfish, $O$. rusticus, has not only reduced snail abundance and species richness (see previous section), but also has had impacts on many other ecosystem components, including macrophytes (Lodge el al. 1994) and congeneric crayfishes (Lodge el al 1986; Olsen et al. 1991). Local extinction of congeners by O. rusiicus is an instructive vehicle for conceptualizing about the most extreme threat of exotics to native species, global extinction.

Olsen et al. (1991) documented that in all of nine northern Wisconsin lakes invaded by O. rusiicus for which long-term data (13 years in this case) existed, abundance of O. rusticus increased, whereas the native congener $O$. virilis declined. We have continued this long-term data set and have observed that the native species is now extinct (as far as our routine sampling methods are able to detect) in four of the same nine lakes (D. M. Lodge and W. L. Perry unpubl. data). A number of mechanisms of this species replacement are now well documented, including competition for food and shelter, and differential vulnerability to predation driven by different sizes (growth rates) and behaviour (DiDonato \& Lodge 1993; Hill et al. 1993; Hill \& Lodge 1994, 1995; Garvey et al. 1994; Willman et al. 1994).

In wider recent surveys in the same region, we have documented current crayfish species composition in 107 lakes and 50 stream reaches (W L. Perry, D. M. Lodge \& G. L. Lamberti unpubl. data). Given that early in this century the only crayfish species in lakes and streams of this region was $O$. virilis (Creaser 1932), we infer that where O. rusticus now occurs and $O$. virilis does not, that the native has been driven extinct by the exotic congener. Of 107 lakes with crayfish, $O$. virilis now occurs in only 47; presumably, it has been driven extinct in the other 60 lakes during the last 25-50 years. Patterns are similar in streams. Of 50 reaches with crayfish, only 19 now contain $O$. virilis; presumably, it has been driven extinct in 31 stream reaches. Clearly, the range and abundance of $O$. virilis in northern Wisconsin is being severely reduced

Table 2. Summary of effects of crayfish and pumpkinseed sunfish on snail assemblages in northern Wisconsin lakes

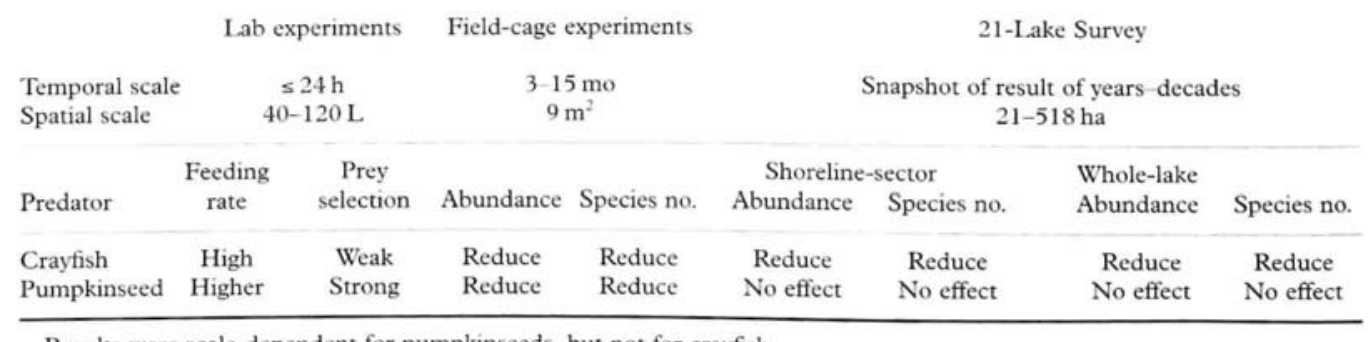

Results were scale-dependent for pumpkinseeds, but not for crayfish.

by $O$. riisricus. However, O. virilis has one of the widest ranges of any North American crayfish (Hobbs \& Jass 1988). Thus, it is not in imminent danger of global extinction.

Many species of crayfishes and other aquatic fauna do, however, have naturally small ranges (Fig. 8). The current conservation status of native North American mussels and crayfishes 
(Master 1990) shows clearly that the smaller the natural range size, the more vulnerable a species is to extinction (Fig. 8). For both native mussels (Mann-Whitney $P<0.001)$ and crayfishes $(\mathrm{P}<$ 0.001), the mean range size of species perceived to be under threat (pooling the categories from 'extinct' through 'special concern') is smaller than that of species that are 'currently stable.'

Many examples exist of the role of exotic species in the global extinction of fishes (Miller et al. 1989; Aquatic Nuisance Species Task Force 1994; Cohen 1994; Pitcher \& Hart 1995). Over the next few years, several species of native unionid mussels will probably go extinct as the North American range of exotic zebra mussels encompasses the ranges of highly endemic unionids in the southeastern US (Bogan 1993; Cummings et al. 1993; Haag et al. 1993; Gillis \& Mackie 1994). Protecting native biodiversity in the face of exotic species (or any other anthropogenic threat) thus requires identifying areas of high endemism (US Congress 1993, $\mathrm{p}$. 40; Cohen 1994). While the ancient great lakes of the world are well-known examples (Cohen 1994), in many regions significant areas of aquatic endemism are unsurveyed and unrecognized.

The currently high rates of species introductions to aquatic ecosystems and subsequent high dispersal within aquatic habitats (and across landscapes with high connectivity between lakes and streams) require that special research and management attention be devoted to preventing widespread global extinction of freshwater biota. The cookie-cutter model of terrestrial species extinctions (Pimm et al. 1995) may apply in extreme form for freshwater ecosystems, especially lakes. In the cookie-cutter model, species extinctions are based on species-area relationships and area of terrestrial habitat destroyed. The best predictions are for island endemics because of the tightly bounded distributions on islands (Pimm et al. 1995).

The same concepts apply with special force to lakes as islands in an inhospitable terrestrial matrix. Once a lake is colonized, the entire lake may quickly be subject to whatever impact the exotic species exerts. Colonization of northern Wisconsin lakes by O. rusticus, and subsequent replacement of $O$. virilis, is just one of many examples. This pattern contrasts with typical terrestrial invasion dynamics. Terrestrial invasions, except on true islands, are less constrained because the habitats are less discrete than for aquatic habitats (lakes especially). Thus, identifying units of the aquatic landscape (e.g. number of lakes or watersheds) that are invasible and that harbour endemics would allow predictions of the impact of an exotic on native biodiversity.

\section{CONCLUSIONS AND RECOMMENDATIONS}

Accidental and intentional transplantation of whole or partial aquatic communities is common, and has produced many significant changes in ecological

Fig. 8. Historic range size in the USA (number of states in which species occurred) for native unionid mussels species [(a) data from Williams et al. 1993] and crayfish species [(b) data from Taylor et al. 1996] in different conservation categories. In a few cases, particularly for crayfishes (C. A. Taylor pers. comm. 1996), the ranges plotted may represent recent anthropogenic range expansions. 


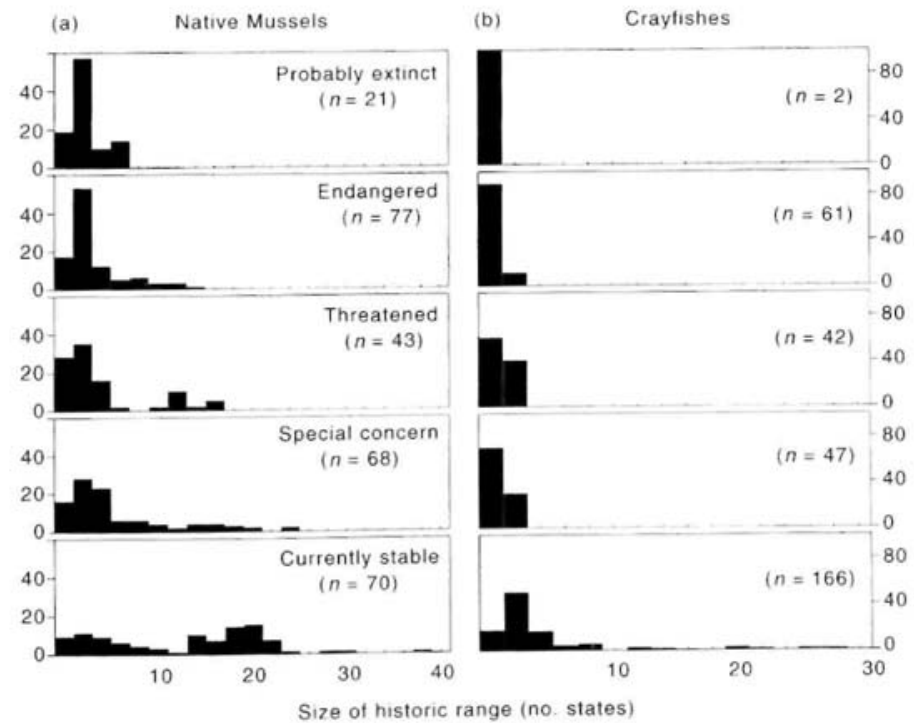

community structure and ecosystem function in many parts of the world. Global homogenization of the world's aquatic biota is well underway, and steps should be taken to slow this dramatically.

To test community theory about invasion-favouring characteristics of species and habitats, and to identify potentially harmful exotic species, we require simultaneous long-term surveys of species being introduced, species becoming established, and species having a significant ecological impact. Without these data, some of which may exist but are not readily available to aquatic ecologists, 'best-guess' assessment of uncertainty based on conceptual models of invasions (Ruesink et al. 1995) is the best we can do, short of experimental work before or early during an invasion.

As demonstrated for pumpkinseed sunfish, the community impact that a given species has cannot be predicted by small-scale experimentation. Large-scale, long-term experiments are most realistic, but are expensive, slow in producing conclusions, and often unacceptable (and often illegal) for not yet established exotics. Yet, they may be appropriate management tools for recently established and still-spreading important, exotic species. Otherwise, scaling algorithms for extrapolating small-scale, short-term experiments to the management scale await discovery.

Because of high impact on native species and high rates of dispersal within a water body, aquatic exotic species may often extirpate native species. The extent to which global extinction occurs depends on the number of landscape units (lakes, stream reaches) in the native range relative to the number of landscape units colonized by the exotic species. Regions with high endemism should be identified and protected from exotic species.

\section{Recommendations for regulation and natural resource management}

Given the currently poor statistical basis for risk analysis and the unpredictably high ecological and economic cost of some exotic species, we concur with Ruesink el al. (1995) in recommending that regulatory agencies assume that any candidate species for introduction is guilty until proven innocent. The reactive mode of natural resource management, e.g. when faced with recently established exotics like zebra mussel and ruffe (Gymnocephalus cernuus) in the North American Great Lakes, has been expensive and unsuccessful.

Clearly, until risk assessment of exotics is more refined, large dividends would be reaped 
by doing the obvious: preventing introduction in the first place with stringently enforced prohibitions on accidental (e.g. ballast water regulations, Chesapeake Bay Commission 1995; Glenn 1996) and intentional (e.g. restrictions and public education regarding the aquarium trade) importation of exotic species, and on rigorous screening and strict management of allowed species. Instead of lists of prohibited species (common practice in the USA and other countries), regulatory agencies should have (short) lists of acceptable species.

\section{ACKNOWLEDGEMENTS}

We thank the many summer helpers at UW-Madison's Trout Lake who collected and processed samples from laboratory experiments, field experiments, and the multi-lake survey: Jason Curole, Ned Haight, Jim Klosiewski, and Edie O'Neal. Steve Blumenshine constructed the figures. Sarah Thompson and Laura Eidietis compiled the data on ranges of unionid mussels and crayfishes. Thanks to Steve Blumenshine, Romi Snively, and Yvonne Vadeboncoeur for constructive criticism on an earlier draft of this paper. DML has benefited from numerous conversations with Gary Lamberti about dispersal of exotics across the freshwater landscape. The following grants funded our research: NSFBSR85-00775, NSFBSR89-07407, EPA CR820290-0T -0 (to DML).

\section{REFERENCES}

Alexander J. E. Jr \& Covich A. P. (1991) Predation risk and avoidance behavior in two freshwater snails. Biol. Bull. $180,1-7$.

Allan J. D. \& Flecker A. S. (1993) Biodiversity conservation in running waters: identifying the major factors that threaten destruction of riverine species and ecosystems. Bioscience 43, 32-43.

Angermeier P. L. \& Karr J. R. (1994) Biological integrity vs biological diversity as policy directives. Bioscience 44, 690-7.

Aquatic Nuisance Species Task Force. (1994,) Findings, Conclusions, and Recommendations of the Intentional Introductions Policy Review. Report to Congress. March 1994. Washington, DC.

Arthington A. H. (1986) Introduced cichlid fish in Australian inland waters. In: Limnology in Australia (eds P. DeDeckker \& W. D. Williams) pp. 239-248. Dr W. Junk Publishers, Boston.

Arthington A. H. \& Bluhdorn D. R. (1995) Improved Management of Exotic Aquatic Fauna: R \& D for Australian Rivers. LWRRDC Occasional Paper no. 4/95. Land and Water Resources Research and Development Corporation, Canberra.

Arthington A. H. \& Mitchell D. S. (1986) Aquatic invading species. In: Ecology of Biological Invasions (eds R. H. Groves \& J. J. Burdon) pp. 34-53. Cambridge University Press, Cambridge.

Bogan A. E. (1993) Freshwater bivalve extinctions (Mollusca: Unionoida): A search for causes. Am. Zool. 33, 599609.

Brönmark C. (1985) Freshwater snail diversity: effects of pond area, habitat heterogeneity and isolation. Oecologia 67, 127-31.

Brönmark C, Klosiewski S. P. \& Stein R. A. (1992) Indirect effects of predation in a freshwater, benthic food chain. Ecology 73, 1662-74.

Brown K. M. \& D. M. Lodge (1993) Gastropod abundance in vegetated habitats: the importance of specifying null models. Liminol. Oceanogr. 38, 217-25.

Cangelosi A. (1996) Biological invasions: Congress takes a second look. Dreissena! 7, 3-5.

Capelli G. M. \& Magnuson J. J. (1983) Morphoedaphic and biogeographic analysis of crayfish distribution in Wisconsin. J. Crust. Biol. 3, 548-64.

Carlton J. T. (1992) Dispersal of living organisms into aquatic ecosystems as mediated by aquaculture and fisheries activities. In: Dispersed of Living Organisms into Aquatic Ecosystems (eds A. Rosenfield \& R. Mann) pp. 13-45. The University of Maryland, Maryland.

Carlton J. T. \& Geller J. B. (1993) Ecological roulette: die global transport of nonindigenous marine organisms. Science 261, 78-82.

Carpenter S. R., Chisholm S. W, Krebs C. J., Schindler D. W. \& Wright R. F. (1995) Ecosystem experiments. Science 269, 324-7.

Chambers P. A., Hanson J. M., Burke J. M. \& Prepas E. E. (1990) The impact of the crayfish Orconectes virilis on aquatic macrophytes. Freshw. Biol. 24, 81-91.

Chesapeake Bay Commission. (1995) The Introduction of Nonindigenous Species to the Chesapeake Bay Via Ballast Water: Strategies to Decrease the Risks of Future Introductions through Ballast Water Management. 
Chesapeake Bay Commission Report. January 5, 1995. Annapolis, Maryland.

Cohen A. S. (1994) Extinction in ancient lakes: biodiversity crises and conservation 40 years after J. L. Brooks. Arch. Hydrobiol. Beih. Ergebn. Limnol. 44, 451-79.

Courtenay W R. Jr \& Stauffer J. R. Jr (1990) The introduced fish problem and the aquarium fish trade. J. World Aquacult. Soc. 21, 145-59.

Covich A. P., Crowl T A., Alexander J. E. Jr \& Vaughn C. C. (1994) Predator-avoidance responses in freshwater decapod-gastropod interactions mediated by chemical stimuli. J. North Am. Benthol. Soc. 13, 283-90.

Covich A. P., Dye L. L. \& Mattice J. S. (1981) Crayfish predation on Corbicula under laboratory conditions. Am. Midl. Nat. 105:181-8.

Creaser E. P. (1932) The decapod crustaceans of Wisconsin. Trans. Wisc. Acad. Sci. Lett. 27, 321-38.

Crowl T. A. \& Covich A. P. (1990) Predator-induced life-history shifts in a freshwater snail. Science 247, 949-51.

Crowl T A. \& Schnell G. D. (1990) Factors determining population density and size distribution of a freshwater snail in streams: effects of spatial scale. Oikos 59, 359-67.

Cullen P. (1990) The turbulent boundary between water science and water management. Freshw. Biol. 24, 201-9.

Cummings K. S., Buchanan A. C. \& Koch L. M. eds (1993) Conservation and management of freshwater mussels. Proceedings of a UMRCC symposium, 12-14 October 1992, St. Louis, Missouri. Upper Mississippi River Conservation Committee, Rock Island, Illinois.

DiDonato G. T \& Lodge D. M. (1993) Species replacements among Orconectes crayfishes in northern Wisconsin lakes: the role of predatory fish. Can. J. Fish. Aq. Sci. 50, 1484-8.

Diamond, J. (1986) Overview: laboratory experiments, field experiments, and natural experiments. In: Community Ecology (eds J. Diamond and T. J. Case) pp. 3-22. Harper \& Row, New York.

Estes J. A. \& Duggins D. O. (1995) Sea otters and kelp forests in Alaska: generality and variation in a community ecological paradigm. Ecol. Monogr. 65, 75-100.

Fasano G. \& Franceschini A. (1987) A multidimensional version of the Kolmogorov-Smirnov test. Monthly Notices Royal Astron. Soc. 225:155-70.

Feminella J. W \& Hawkins C. P. (1995) Interactions between stream herbivores and periphyton: a quantitative analysis of past experiments. J. North Am. Benthol. Soc. 14, 465-509.

Feminella J. W. \& Resh V. H. (1989) Submersed macrophytes and grazing crayfish: an experimental study of herbivory in a California freshwater marsh. Holarctic Ecol. 12, 1-8.

Flecker A. S. \& Townsend C. R. (1994) Community-wide consequences of trout introduction in New Zealand streams. Ecol. Appl. 4, 798-807.

Fletcher A. R. (1986) Effects of introduced fish in Australia. In: Limnology in Australia (eds P. De Decker \& W. D. Williams) pp. 231-8. Dr W Junk Publishers, Boston.

Frost T. M., DeAngelis D. L., Bartell S. M., Hall D. J. \& Hurlbert S. H. (1988) Scale in the design and interpretation of aquatic community research. In: Complex Interactions in Lake Communities (ed S. R. Carpenter) pp. 229-60. Springer-Verlag, New York.

Garvey J. E., Marschall E. A. \& Wright R. A. From star charts to stoneflies: detecting relationships in continuous bivariatc data. Ecology (in press)

Garvey J. E., Stein R. A. \& Thomas H. M. (1994) Assessing how fish predation and interspecific prey competition nfluence a crayfish assemblage. Ecology 75, 532-47.

Giller P. S,, Hildrew A. G. \& Rafaelli D. G. (1994) Aquatic Ecology: Scale, Pattern and Process. Blackwell Science, Oxford.

Gillis P. L. \& Mackie G. L. (1994) Impact of me zebra mussel, Dreissena polymorpha, on populations of Unionidae (Bivalvia) in Lake St. Clair. Can. J. Zool. 72, 1260-71.

Glenn J. (1996) Floor statement of Senator John Glenn: National Invasive Species Act of 1996. Dreissena! 7, 1-3.

Grosholz E. D. (1996) Contrasting rates of spread for introduced species in terrestrial and marine systems. Ecology 77, 1680-6.

Haag W. R., Berg D. J., Garton D. W. \& Farris J. L. (1993) Reduced survival and fitness in native bivalves in response to fouling by the introduced zebra mussel (Dreissena polymorpha) in western Lake Erie. Can. J. Fish. Aq. Sci. 50, 13-19.

Hanson J. M., Chambers P. A. \& Prepas E. E. (1990) Selective foraging by the crayfish Orconectes virilis and its impact on macroinvertebrates. Freshw. Biol. 24, 69-80.

Hill A. M. \& Lodge, D. M. (1994) Diel changes in resource demand: interaction of competition and predation in species replacements by an exotic crayfish. Ecology 75, 2118-26.

Hill A. M. \& Lodge D. M. (1995) Multi-trophic-level impact of sublethal interactions between bass and omnivorous crayfish. J. North Am. Benthol. Soc. 14, 306-14. 
Hill A. M., Sinars D. M. \& Lodge D. M. (1993) Invasion of an occupied niche by the crayfish Orconectes rusticus: potential importance of growth and mortality. Oecologia 94, 303-6.

Hobbs H. H. III \& Jass J. P. (1988) The Crayfishes \& Shrimps of Wisconsin. Milwaukee Public Museum, Milwaukee, WI.

Hobbs H. H. III, Jass J. P. \& Huner J. V. (1989) A review of global crayfish introductions with particular emphasis on two North American species (Decapoda: Cambaridae). Crustaceana 56, 299-316.

Hutchings P. (1992) Ballast water introductions of exotic marine organisms into Australia: current status and man agement options. Mar. Poll. Bull. 25:196-9.

Johnson L. E. \& Carlton J. T. (1996) Post-establishment spread in large-scale invasions: dispersal mechanisms of the zebra mussel Dreissena polymorpha. Ecology 77:1686-90.

Jones C. G. \& Lawton J. H. eds (1995) Linking Species and Ecosystems, Chapman \& Hall, New York.

Karieva P. M. \& Andersen M. (1988) Spatial aspects on species interactions: the wedding of models and experiments. In: Community Ecology (ed A. Hastings) pp. 38-54. Springer-Verlag, New York.

Kershner M. W. \& Lodge D. M. (1995) Effects of littoral habitat and fish predation on the distribution of an exotic crayfish, Orconeaes rusticus, J. North Am. Benthol. Soc. 14, 41422.

Klosiewski S. P. (1991) The role of pumpkinseed sunfish in structuring snail assemblages in northern Wisconsin lakes. PhD thesis. The Ohio State University, Columbus, OH, USA.

Krebs C. J. (1989) Ecological Methodology. Harper \& Row, New York.

Lodge D. M. (1993a) Biological invasions: Lessons for ecology. Trends Ecol. Evol. 8, 133-7.

Lodge D. M. (199 3b) Species invasions and deletions: Community effects and responses to climate and habitat change. In: Biotic Interactions and Global Change (eds P. M. Kareiva, J. G. Kingsolver \& R. B. Huey) pp. 367-87. Sinauer Associates Inc., Sunderland.

Lodge D. M.s Blumenshme S. C. \& Vadeboncoeur Y (1997) Insights and applications of large-scale, long-term eco logical observations and experiments. In: The State of Experimental Ecology: Questions, Levels and Approaches, (eds W. J. Resetarits \& J. Bernardo). Oxford University Press, Oxford (in press).

Lodge D. M., Brown K. M., Klosiewski S. P. et al. (1987) Distribution of freshwater snails: spatial scale and the relative importance of physicochemical and biotic factors. Am. Malacol. Bull. 5, 73-84.

Lodge D. M. \& Hill A. M. (1994) Factors governing species composition, population size, and productivity of coolwater crayfishes. Nordic J. Freshw. Res. 69, 11136.

Lodge D. M., Kershner M. W., Aloi J. E. \& Covich A. P. (1994) Effects of an omnivorous crayfish (Orcoucctcs rusticus) on a freshwater littoral food web. Ecology 75, 1265-81.

Lodge D. M., Kratz T. K. \& Capelli G. M. (198b) Long-term dynamics of three crayfish species in Trout Lake, Wisconsin. Can. J. Fish. Aq. Sci, 43, 993-8.

Lodge D. M. \& Lorman J. G. (1987) Reductions in submersed macrophyte biomass and species richness by the crayfish Orconectes rusticus. Can. J. Fish. Aq. Sci. 44, 591-7.

Ludwig H. R. Jr \& Leitch J. A. (1996) Inter-basin transfer of aquatic biota via anglers' bait buckets. Fisheries 21, 14-18.

Manly B. F. J. (1991) Randomization and Monte Carlo Methods in Biology. Chapman \& Hall, New York.

Master L. (1990) The imperiled status of North American aquatic animals. Biodivers. Network News 3, 5-8.

Matthews M. \& Reynolds J-D. (1992) Ecological impact of crayfish plague in Ireland. Hydrobiologia 234, 1-6.

McMahon R. F. (1991) Mollusca: Bivalvia. In: Ecology and Classification of North American Freshwater Invertebrates (eds J. H. Thorp \& A. P. Covich) pp. 315-400. Academic Press, New York.

Miller R. R., Williams J. D. \& Williams J. E. (1989) Extinctions of North American fishes during the last century. Fisheries 14, 22-38.

Mills E. L., Leach J. H., Carlton J. T \& Secor C. L. (1993) Exotic species in the Great Lakes: A history of biotic crises and anthropogenic introductions. J. Gt. Lakes Res. 19, 1-54.

Mills E. L., Leach J. H., Carlton J. T \& Secor C. L. (1994) Exotic species and the integrity of the Great Lakes: Lessons from the past. Bioscience 44, 666-76.

Mills E. L., Strayer D. L., Scheuerell M. D. et al. (1996) Exotic species in the Hudson River basin: A history of invasions and introductions. Estuaries 19, 81423.

Mitchell D, S. (1986) Aquatic macrophytes and man. In: Limnology in Australia (eds P. DeDeckker \& W. D. Williams) pp 587-98. Dr W. Junk Publishers, Boston.

Mittelbach G. G. (1984) Predation and resource partitioning in two sunfishes (Centrarchidae). Ecology 65, 49951 3.

Moyle P. B. \& Light T. (1996) Fish invasions in California: do abiotic factors determine success? Ecology 77, 166670. 
Murdoch W. W. \& Bcnce J. (1987) General predators and unstable prey populations. In: Predation: Direct and Indirect Impacts on Aquatic Communities (eds W. C. Kerfoot \& A. Sih) pp. 17-30. University Press of New England, Hanover.

Nesler T. P. \& Bergersen E. P. eds (1991) Mysids in fisheries: hard lessons from headlong introductions. American Fisheries Society Symposium 9, Bethesda, Maryland.

Neves R. J. (1993) A state-of-the-unionids address. In: Conservation and Management of Freshwater Mussels (eds K. S. Cummings, A. C. Buchanan \& L. M. Koch) pp. 1-10. Proceedings of a UMRCC symposium, 12-14 October 1992, St Louis, Missouri. Upper Mississippi River Conservation Committee, Rock Island, Illinois.

Olsen T. M., Lodge D. M., Capelli G. M. \& Houlihan R. J. (1991) Mechanisms of impact of three crayfish congeners (Orconectes spp.) on littoral benthos. Can. J. Fish. Aq. Sci. 48, 1853-61.

Osenberg C. W. \& Mittelbach G. G. (1989) Effects of body size on the predator-prey interaction between pumpkinseed sunfish and gastropods. Ecol. Monogr. 59, 405-32.

Perry W L., Lodge D. M. \& Lamberti G. A. (1997) Impact of crayfish predation on exotic zebra mussels and native invertebrates in a lake-outlet stream. Can. J. Fish. Aq. Sci. (in press).

Pimm S. L. (1991) The Balance of Nature. University of Chicago Press, Chicago.

Pimm S. L., Russell G. J., Gittleman J. L. \& Brooks T. M. (1995) The future of biodiversity. Science 269, 347-50.

Pitcher T. J. \& Hart P. J. B. (eds) (1995) The Impact of Species Changes in African Lakes. Chapman \& Hall, London.

Pollard D. A. \& Hutchings P. A. (1990a) A review of exotic marine organisms introduced to the Australian region. I. Fishes. Asian Fish. Sci. 3, 205-21.

Pollard D. A. \& Hutchings P. A. (1990b) A review of exotic marine organisms introduced to the Australian region. I. Invertebrates and algae. Asian Fish. Sci. 3, 223-50.

Press W. H., Teukolsky S. A., Vetterling W. T. \& Plannery B.P (1992) Numerical Recipes in C. Cambridge University Press, Cambridge.

Rejmanek M. \& Richardson D. M. (1996) What attributes make some plant species more invasive? Ecology 77, 1655-61.

Ruesmink J. L., Parker I. M., Groom M. J. \& Karieva P. M. (1995) Reducing the risks of nonindigenous species introductions: Guilty until proven innocent. Bioscience 45, 465-77.

Schmitz D. C, Nelson B. V, Nail L. E. \& Schardt J. D. (1991) Exotic aquatic plants in Florida: a historical perspective and review of the present aquatic plant regulation program. In: Proceedings of the Symposium on Exotic Pest Plants (eds T. D. Center, R. F. Doren, R. L. Hoffstetter, R. L. Myers \& L. D. Whiteaker). pp. 303-23. University of Miami, Miami.

Schulze E-D. \& Mooney H. A. eds (1993) Biodiversity and Ecosystem Function. Springer-Verlag, New York.

Taylor C. A., Warren M. L. Jr \& Fitzpatrick J. F. Jr (1996) Conservation status of crayfishes of the United States and Canada. Fisheries 21, 25-38.

Thorp J. H. (1986) Two distinct roles for predators in freshwater assemblages. Oikos 47, 75-82.

Tilman D. (1989) Ecological experimentation: strengths and conceptual problems. In: Long-term Studies in Ecology (ed. G. E. Likens) pp. 136-57. Spnnger-Verlag, New York.

Tilman D., Wedin D. \& Knops J. (1996) Productivity and sustainability influenced by biodiversity in grassland ecosystems. Nature 379, 718-20.

US Congress. (1993) Harmful Non-Indigenous Species in the United States. Office of Technology Assessment, OTA-F565, September 1993. US Government Printing Office, Washington, DC.

Vermeij G. J. (1991) When biotas meet: Understanding biotic interchange. Science 253, 1099-104.

Veltman C. J., Nee S. \& Crawley M. J. (1996) Correlates of introduction success in exotic New Zealand birds. Am, Nat. 147,542-57.

Vermaat J. E. (1994) Periphyton removal by freshwater micrograzers. In: Lake Veluwe, a Macrophyte-dominated System under Eutrophication Stress (eds W. van Vierssen et al.) pp. 213 49. Kluwer Academic Publishers, Netherlands.

Vitousek P. M. (1990) Biological invasions and ecosystem processes: towards an integration of population biology and ecosystem studies. Oikos 57, 247-65.

Vitousek P. M., D'Antonio C. M., Loope L. L. \& Westbrooks R. (1996) Biological invasions as global environmental change. Am. Sci. 84, 46877.

Weber L. M. \& Lodge D. M. (1990) Periphyton food and crayfish predators: relative roles in determining snail distributions. Oecologia 82, 33-9.

Williams J. D., Warren M. L. Jr, Cummings K. S., Harris, J. L. \& Neves R. J. (1993) Conservation status of freshwater mussels of the United States and Canada. Fisheries 18, 6-22. 
Williamson M. \& Fitter A. (1996) The varying success of invaders. Ecology 77, 1661 -6.

Willman E. J., Hill A, M. \& Lodge D. M. (1994) Response of three crayfish congeners (Orconeetes spp.) to odors of fish carrion and live predatory fish. Am. Midl. Nat. 132, 44-51. 